\title{
BUSINESS PLANNING OF HUMAN RESOURCES MANAGEMENT: THE HOSPITAL CLASS ENHANCING PROGRAM - FROM CLASS D TO BE CLASS C
}

\author{
Warsini Anastasia*, Student \\ Syah Tantrin Yanuar Rahmat, Kusumapradja Rokiah, Erni Nofi, Lecturers \\ Faculty of Economic and Business, Esa Unggul University, Indonesia \\ *E-mail: annawrsn9@gmail.com \\ ORCID: 0000-0003-4919-6908
}

\begin{abstract}
Preparing human resources for the hospital class improvement is very important because the human resources in the hospital is an important asset with a variety of their respective fields, both professionals and personnel who support it. When preparing human resources we need to know what kind of services that will be given, so we can predict the number and type of personnel who will provide for the service. Pademangan Regional General Hospital conducting its business by using hold and maintenance strategy with the main strategy of market penetration require reliable and skilled human resources in marketing the excellent service type which is owned by professional so that people get to know Pademangan General Hospital. The government has regulated amount and type of labor requirements required in accordance with the hospital class by the method of counting to the workload and the level of dependence of the patient for determining Human Resources. Human resource management start from job analysis that will be given to the employee, making job description, recruitment, new employee orientation, training, seminar and workshop. Training adjusted by the needs of the company to produce employees with dedication and high integrity.
\end{abstract}

\section{KEY WORDS}

Strategy, management, hospital staff, human resource.

Referring to the Republic of Indonesia's Law number 44 of 2009 about hospitals that the health service is the right of every person guaranteed in the 1945 Constitution of the Republic of Indonesia which must be realized with the effort to improve the highest level of public health. In addition, the hospital is a health service institution for people who provide services and have a specific in terms of human resources, infrastructure, and equipment used. Although it has characteristics that are slightly different from other industries.

In the National Health Insurance (JKN) era the governments command the Indonesian people to participate in the Indonesian public health improvement program with BPJS health insurance. In the implementation of the program the hospital as a place of health care providers receive policies regulated by the government, especially about the payment of patient care costs for hospital treatment. There is a significant difference between class $D$ hospitals with class $C$ hospitals, which is higher cost rates for the same illness and cases in class $\mathrm{C}$, therefore the preparation of human resources is essential for the improvement of the hospital class.

\section{LITERATURE REVIEW}

Human resource management is a study or a way to manage how the relationship and role of manpower work effectively and efficiently so that it can be maximized to achieve common goals, both for the company and for the employees themselves. Human resource management used to manage people, it is important because within the organization or company employees become the driving force of the life of the company. Human Resource Management has two functions: managerial functions and operational functions. Managerial functions include planning, organizing, directing, and controlling. While the operational 
function is the procurement of labor, development, integration, maintenance, compensation and termination of employment.

In the hospital industry, employees are an important asset with a variety of respective fields, both professionals and workers who support it. In addition the hospital is a capitalintensive and labor-intensive enterprise, so that required good human resource management in accordance with competency standard. Similarly, in terms of energy needed in the hospital industry is very different from the company in general. For that government set in Permenkes number 56 year 2014 about the needs of medical and non-medical personnel in accordance with the hospital class.

In performing its functions human resource management to create a strategy to manage resources owned, it can be described as seen in Table 1.

Table 1 - Human Resource Management Strategy

\begin{tabular}{|c|c|c|}
\hline Function & Strategy & Activity \\
\hline \multirow{3}{*}{ Managerial } & $\begin{array}{l}\text { Analysis and } \\
\text { design of work }\end{array}$ & $\begin{array}{l}\text { Identify tasks, duties (duty), and responsibilities (Kaswan, 2012: 19) } \\
\text { The hospital identifies the required profession, as well as determines the qualifications } \\
\text { appropriate to the task to be performed. }\end{array}$ \\
\hline & $\begin{array}{l}\text { Human } \\
\text { Resource } \\
\text { Planning }\end{array}$ & $\begin{array}{l}\text { Human Resource Planning involves how many people are required to perform the activities } \\
\text { assigned, and what to do (Kaswan, } 2012: 20 \text { ) } \\
\text { Ensure that the organization has the right amount of human resources, available the right } \\
\text { type of workforce, available at the right time, for the right position or place, and doing the } \\
\text { right job. } \\
\text { The hospital plannedthe type of services, qualifications and workloads. }\end{array}$ \\
\hline & Recruiting & $\begin{array}{l}\text { Activities undertaken by the organization in order to identify and attract potential qualified } \\
\text { employers. The hospital should undertake a recruitment process by specifying recruitment } \\
\text { methods, listing candidates, selecting eligible candidates, make deals with elected } \\
\text { candidates and pass the selection. }\end{array}$ \\
\hline \multirow{5}{*}{ Operational } & Selection & $\begin{array}{l}\text { The process which the organization identifies applicant knowledge, skills, abilities and other } \\
\text { characteristics that needed to assist the organization to achieve the goal (Sekiguchi, 2004). } \\
\text { In conducting the selection of hospital staff candidates set in Governor Regulation no } 837 \text { of } \\
2015 \text { on the selection of the Department of Health DKI Jakarta Province. }\end{array}$ \\
\hline & $\begin{array}{l}\text { Training and } \\
\text { Development }\end{array}$ & $\begin{array}{l}\text { Training and development is very important in the company. Training refers to the need for } \\
\text { skills currently, while the development is for the future. } \\
\text { In the need to improve the quality of service and professionalism for employees hospital } \\
\text { conduct training, both internal and external so that employees have the same standards in } \\
\text { providing services to patients and families. The hospital also conducts development for } \\
\text { employees for the future of the hospital. }\end{array}$ \\
\hline & Compensation & $\begin{array}{l}\text { Compensation that receive by employees on a regular basis, whether in the form of wages or } \\
\text { salaries. Hospitals provide fixed compensation (salary or wages), compensation of variables } \\
\text { (bonuses, incentives, commissions) and non-financial compensation benefits received by } \\
\text { employees for good performance outcomes in the form of praise, recognition, self-esteem, } \\
\text { achievement, responsibility, progress, development. }\end{array}$ \\
\hline & $\begin{array}{l}\text { Performance } \\
\text { management }\end{array}$ & $\begin{array}{l}\text { Performance management is defined as the way managers ensure that employee activities } \\
\text { and work results are consistent with organizational goals (Aguinis, 2009). Hospital } \\
\text { performance is reflected in the performance of its employees, demonstrated by ownership, } \\
\text { full of responsibility and high loyalty. }\end{array}$ \\
\hline & $\begin{array}{l}\text { Employee } \\
\text { Relations }\end{array}$ & $\begin{array}{l}\text { In a hospital organization the work environment will provide comfort, feel involved, } \\
\text { understandably and trust each other so that employees will work well. Hospitals should have } \\
\text { Value (value that is applied in work culture in hospital). So all employees in carrying out their } \\
\text { duties and work apply the values of organizational culture. }\end{array}$ \\
\hline
\end{tabular}

\section{FRAMEWORK OF STUDY}

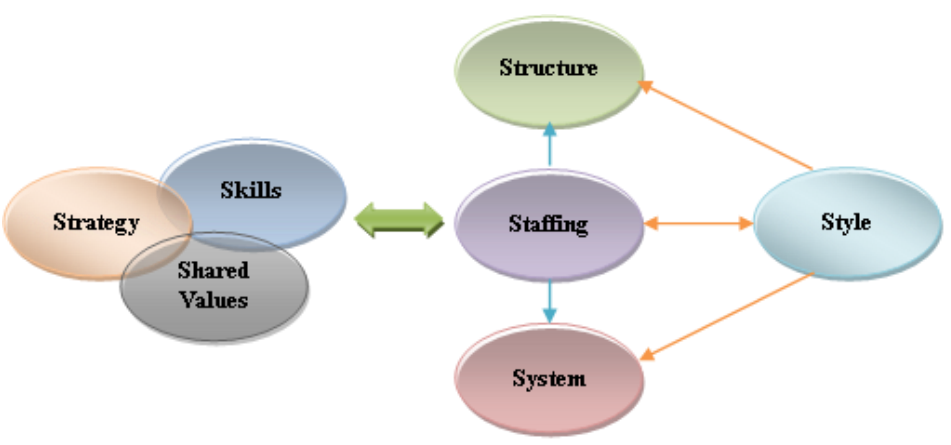

Figure 1 - Research Framework (Source: Harvard Business School Management Consulting Club) 
In running the operational of Pademangan Public Regional Hospital, McKinsey 7S framework is being used. In running the hospital business, the hospital uses strategy based on internal and external analysis. From those analysis, Pademangan Public Regional Hospital use Market Penetration strategy. Market Penetration is a growth strategy where a company focuses on selling the products which are in the market before while maintaining the hospital service quality and improving the facility by adding services based on android and Apple.

This model shows a relationship between leader, organization culture, and strategy. Mc Kinsey elaborates that strategy (strategy) that agreed by the leaders have to be supported by organization structure (structure) and system (system) applied on that organization. Those structure and system are decided by leader (Style). Leader decided who will help him (staff) and skills own by those staffs. Structure, system, style, staff and skill contributes to the success of the strategy. Contribution from 5S (structure, system, style, staff and skill) blend into one variable called Shared Value or as we know Culture (Organization Culture) (Pearce and Robinson, 2000).

Strategy is a way chosen by organization for it's future or a plan designed by organization to get sustainable competitive advantage. In running business, hospital uses strategy based on result of external and internal hospital analysis. After running an internal analysis (strength, weakness) and external analysis (opportunity, threat) it yields a correct strategy for developing organization or hospital.

Organization culture is a set of belief and attitude applied between the member of organization. Culture that adapts and pushes member involvement could brighten the goals and the direction of operational strategy and teaches values and beliefs that could help organization reach the growth, reach the target, and earn profit and give higher satisfaction for the customers (Darmawan, 2013).

Skill is a unique ability owned by the employee which different an organization from others. To support strategy chosen, hospital provides medical staffs that have skill in operating the hospital. Each one of the profession has specific skill to carry on the job. One skill that has to be in every employee is communicated on. This is very important because every activity require verbal or non-verbal communication. Because of that hospital prepare marketing staffs that promotes hospital services provided by the hospital. The marketing staffs has to be able to use strategy to aim the market so people could be interested in using service provided by Pademangan Public Regional Hospital. Aside from the marketing staff, hospital should provide staff to handle the application as a higher service for the customers, so the customers could get the healthcare easier. Skill doesn't happen overnight, skill needs training and education, interprofessional workshop, internal and external. General training starts from front line to back office. General training like basic life support, disaster management, fire management, hand hygiene, effective communication, and excellent service are very important.

Training for nurses focuses on competency that has to be owned depend on the career in nurses. For medical skill and nursing skill, they had to be given an emergency training, methods used are bedside teaching, classes and mentoring for new nurses.

Structure is a frame where activity of the members is coordinated. Organization structure is a composition from different components or work unit in an organization. In this structure there are division of work and how functions are being coordinated and there is also line of command and presentation of report. The function in organization is to give information to the employee to know the activity or job that they have to do, consulting and responsible to whom, so the process to reach a goal could be succeeded as planned.

Staff is a human resource in an organization; according to how employee trained, built, socialized, integrated, motivated, and how their career managed. In organization structure this belongs to Human Resource Development that has training and development program to manage employee so they could become trained ones. Having a wide knowledge, good ethics in providing service. Integrated coordination is need from every part of the hospital, not only doctors and nurses but also every department are trained to have equivalent position based on their part in giving health service. Service staff help leader in carrying on the task, 
In giving service to all the line in organization. The main function in service staff is to give the best service in a form of operational activity, not giving advice or judgment. Every staff in hospital carry on the work based on decided job description, so they can give fast and correct service professionally.

System is informal and formal procedure, innovation system included, compensation system, management of information system, capital allocation system that decide everyday activity. System is translated on decision, guidelines, ways, and standard operational procedure. System manage could be in a manual or electronic form. Hospital built on integrated service system could give satisfaction to patients and their family. Reciprocally in managing employee, it should be one system that provide quality employee with a standardized recruitment process, training with socialization and development of the employee for the organization.

Leadership in organization or company is needed. An ideal leader has to be able to persade, motivate, push people into giving contribution and work effectively until reaching a success by a company or organization. The leadership style often had by the leaders is transformational leadership. This leadership points to positive changes to the subordinate. Transformational leaders mostly are energetic, enthusiastic, passionate, not only the leaders pay attention and get involved but also are focused on helping every member of the organization to succeed. Hospital Leader (directors) have qualification listed, is a doctor that have skill to manage hospital.

The need of hospital staff is based on staffing standard of the government regulations, consist of doctors, specialists, dentist, nurses, midwifes, dental nurses, pharmacist, pharmacy assistant, nutritionist, sanitarian, medical analysis, radiographer, physiotherapist, medical record, refractions, electro medic staff, public relation, structural board, and functional staff. This need refer to work load. For example, calculating the need of nurses could be done referring to Depkes (2003): Calculating the amount of nurses are influenced by patient dependency, room lay out, diagnostic test outside the care room. According to Depkes (2003) this calculation based on patient dependency, the amount of patient a day, hours of care that needed/day/patient, the hours of room/day, effective work hour every nurse.

Based on the level of dependence of nursing care patients are divided into: (1) Minimal nursing care 2 hours / 24 hours include personal hygiene, bathing, clothes changing by their own, eating and drinking by their own, ambulation with supervision, vital signs observation every shift, minimal treatment, stable psychological status. (2) moderate nursing care 3,08 hours / 24 hours include; personal hygiene aided, aided eating and drinking, vital signs observation every 4 hours, assisted ambulation, treatment more than once. (3) Heavy nursing care 4.15 hours / 24 hours covering assisting most activities, vital signs observation every 2 to 4 hours, equipped with folley catheter and recorded intake \& output, equipped with infusion, treatment more than once, treatment with necessary preparation (4) Maximum nursing care 6.16 hours / 24 hours include; all activities are assisted by nurse, arranged position, vital signs observation every 2 hours, feeding patients using Naso Gastric Tube, intra venous therapy, suction utilization.

Calculation Number of Effective Days of Nurse and calculation of nurse staff:

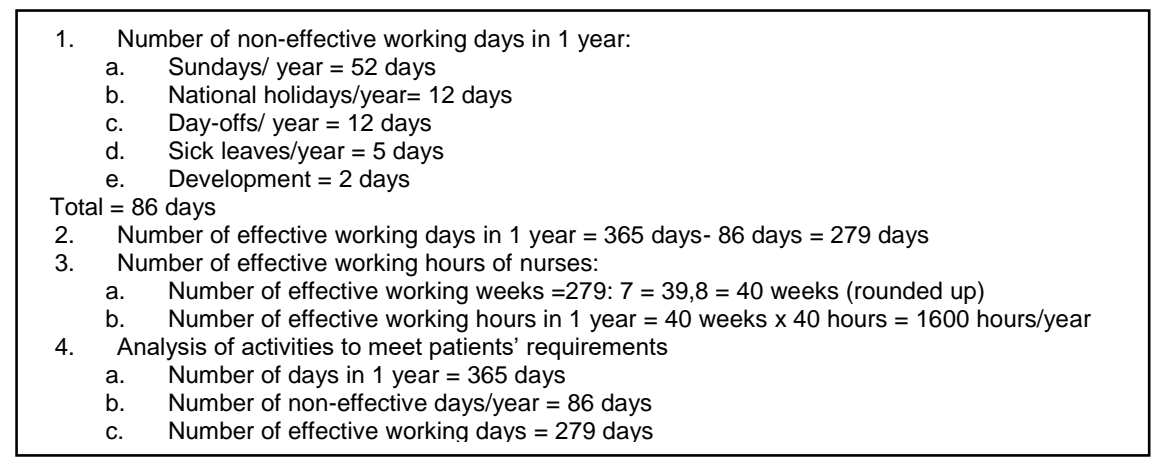

Example of treatment rooms requirement's calculating: number of beds - 19; average number of patients per day - 18. 
Table 2 - Average Number of Patients per Day

\begin{tabular}{llll}
\hline Categories & Average $\Sigma$ patients/day & $\sum$ Hours & $\sum$ Treatments \\
\hline Minimal nursing care & - & 2 & - \\
Moderate nursing care & 2 & 3,08 & 6,16 \\
Heavy nursing care & 13 & 4,15 & 53,9 \\
Maximum nursing care & 3 & 6,16 & 18,4 \\
Total & 18 & & 78,5 \\
\hline
\end{tabular}

$\sum$ required nurses: $\frac{\sum \text { treatment hours } / \text { day }}{\text { Effectiveworking hours } / \text { shift }}=\frac{78,5}{7}=11,2$

$$
\text { Loss day: } \frac{\sum \text { Non-effectivedays }}{\text { Effectiveworkingday hours }} \times \sum \text { nurses }=\frac{86}{279} \times 11,2=3,4
$$

Correction 25\% (non-nursing tasks): $=\frac{25}{100} x\left(\sum\right.$ nurse staffs + loss day $)=\frac{25}{100} x(11,2+3,4)=3,65$

Total required nurses: $11,2+3,4+3,65=18,25=18$ person $+1 \mathrm{Ka}$. Unit +1 Maternal leave $=20$ person

Ministry of Health Decree No. 81 / MENKES / SK / I / 2004 on guidelines for the arrangement of human resources of health at provincial, regency / municipality level and hospitals is a guideline used for planning of supply and demand Source of Workload Indicator Staffing Need (WISN), as the method described is an indicator that shows the amount of personnel requirements on health facilities is based on workload, therefore location / relocation will be easier and rational. namely:

The human resource requirements calculation based on WISN includes 5 steps,

- Determining available working time;

- Establishing working units and HR categories;

- Arranging workload standards;

- Arranging permission standards;

- The calculation of personnel requirements per work unit.

Table 3 - Class C Hospital Personnel Requirements

\begin{tabular}{|c|c|c|c|c|c|}
\hline \multirow{2}{*}{ No } & \multirow{2}{*}{ Occupation } & \multirow{2}{*}{ Available number } & \multicolumn{2}{|l|}{ Consist off } & \multirow{2}{*}{ Additional } \\
\hline & & & Government employee (GE) & Non GE & \\
\hline 1 & Medical Specialist & 13 & 1 & 12 & 5 \\
\hline 2 & General Practitioner & 10 & 4 & 6 & 1 \\
\hline 3 & Dentist & 2 & 1 & 1 & 0 \\
\hline 4 & Nurse & 43 & 2 & 41 & 6 \\
\hline 5 & Midwife & 15 & 3 & 12 & 0 \\
\hline 6 & Dental nurse & 2 & - & 2 & 0 \\
\hline 7 & Pharmacist & 2 & - & 2 & 6 \\
\hline 8 & Pharmacist assistant & 7 & 1 & 6 & 0 \\
\hline 9 & Nutritionist & 3 & - & 3 & 0 \\
\hline 10 & Sanitarian & 2 & 1 & 1 & 0 \\
\hline 11 & Medical Analyst & 8 & - & 8 & 0 \\
\hline 12 & Radiographer & 5 & - & 5 & 0 \\
\hline 13 & Physiotherapist & 2 & - & 2 & 0 \\
\hline 14 & Medical record staff & 3 & - & 3 & 1 \\
\hline 15 & Refractionist & - & - & - & 1 \\
\hline 16 & Electromedical engineer & 1 & - & 1 & 1 \\
\hline 17 & Public Relation, Marketing & 1 & - & 1 & 1 \\
\hline 18 & Structural staff & 4 & - & 4 & 0 \\
\hline 19 & General functional staff & 71 & 3 & 68 & 0 \\
\hline
\end{tabular}

\section{CONCLUSION}

In order to improve the hospital class, reliable personnel are required to run the strategy and plan. Changes in labor standards should be in accordance with the requirements for licensing for hospital grade improvement. In terms of the addition of the 
number of personnel, personnel specification improvement is needed to meet the service target. To add the number of personnel, improvement of knowledge and skills of the caregivers who serve the patient. Therefore, the quality of services provided becomes improved.

\section{REFERENCES}

1. Aguinis, H. (2009). Performance management. Upper Saddle River, NJ: Pearson Prentice Hall.

2. Darmawan, D. (2013). Prinsip-prinsip perilaku organisasi. Surabaya: Pena Semesta.

3. Fred R., \& David. (2011). Strategic Management Consept and Cases. New Jersey. Prentice Hall.

4. Kaswan. (2012). Manajemen Sumber Daya Manusia. Yogyakarta: Graha Ilmu

5. Keputusan Menetri Kesehatan RI Nomor 81/MENKES/SK/I/2004 tentang pedoman penyusunan SDM kesehatan di Tingkat Provinsi, Kabupaten/Kota

6. Mangun, W. (2012). Manajemen Sumber Daya Manusia. Jakarta: Erlangga

7. Pearce, J. A., Robinson, R. B., \& Subramanian, R. (2000). Strategic management: Formulation, implementation, and control. Columbus, OH: Irwin/McGraw-Hill.

8. Republik Indonesia. 2009. Undang-Undang No. 44 Tahun 2009 Tentang Rumah Sakit. Sekretariat Negara. Jakarta

9. Republik Indonesia. 2014. Peraturan Menteri Kesehatan Nomor 56 Tentang Klasifikasi dan Perizinan Rumah Sakit Tahun 2014.Sekretariat Menteri Kesehatan. Jakarta

10. Sekiguchi, T. (2004). Person-organization fit and person-job fit in employee selection: A review of the literature. Osaka keidai ronshu, 54(6), 179-196.

11. Undang-undang No. 36 Tahun 2014 Tentang Tenaga Kesehatan 